\title{
Modeling Nutrient Transports and Exchanges of Nutrients Between Shallow Regions and the Open Baltic Sea in Present and Future Climate
}

\author{
Kari Eilola, Elin Almroth Rosell, Christian Dieterich, \\ Filippa Fransner, Anders Höglund, \\ H. E. Markus Meier
}

\begin{abstract}
We quantified horizontal transport patterns and the net exchange of nutrients between shallow regions and the open sea in the Baltic proper. A coupled biogeochemical-physical circulation model was used for transient simulations 1961-2100. The model was driven by regional downscaling of the IPCC climate change scenario A1B from two global General Circulation Models in combination with two nutrient load scenarios. Modeled nutrient transports followed mainly the large-scale internal water circulation and showed only small circulation changes in the future projections. The internal nutrient cycling and exchanges between shallow and deeper waters became intensified, and the internal removal of phosphorus became weaker in the warmer future climate. These effects counteracted the impact from nutrient load reductions according to the Baltic Sea Action Plan. The net effect of climate change and nutrient reductions was an increased net import of dissolved inorganic phosphorus to shallow areas in the Baltic proper.
\end{abstract}

Keywords Modeling - Transports - Nutrients ·

Baltic Sea $\cdot$ Coastal exchange $\cdot$ Climate

\section{INTRODUCTION}

The Baltic Sea (Fig. S1, Electronic supplementary material) salinity is controlled by the large freshwater supply and the water exchange with the North Sea (e.g. Leppäranta and Myrberg 2009). Meier (2007) calculated the pathways and ages of various water masses with the high resolution ocean circulation model, Rossby Centre Ocean model (RCO),

Electronic supplementary material The online version of this article (doi:10.1007/s13280-012-0322-1) contains supplementary material, which is available to authorized users. which is used in the present study. For the surface layers, he found that mean ages associated to inflowing saline water from Kattegat ranged from about 26 years in the south to 42 years in the most northern Baltic Sea. Because of the long water residence time and the salinity induced density stratification that hamper the ventilation of deep waters, oxygen deficiency is a common feature in the Baltic Sea.

\section{Impact of Nutrient Loads and Changing Climate}

The biogeochemical cycling in coastal seas and especially in areas of restricted water exchange are affected by increasing pressures from human activities and population growth (Rabalais et al. 2010). Increased anthropogenic nutrient loads (Conley et al. 2011; Gustafsson et al. 2012) and increased water temperatures that are especially pronounced in enclosed northern European seas (Philippart et al. 2011) are important environmental factors that affect the Baltic Sea ecosystems. The annual mean surface water temperature in the Baltic Sea is in future scenarios expected to increase by some $2-4{ }^{\circ} \mathrm{C}$ (BACC Author Team 2008). Climate change studies using coupled hydrodynamic-biogeochemical models for the Baltic Sea have recently been initiated. These studies have focused on changes in the state of ecological quality indicators such as oxygen, phytoplankton, and the pools of nutrients in water and sediment (Neumann 2011; Meier et al. 2011a, b, 2012a, b). The lower solubility of oxygen in warmer waters, the possible faster decomposition rates of organic matter and increased productivity influence the bottom water oxygen concentrations negatively by increased oxygen consumption and reduced supply of new oxygen (Meier et al. 2012a). Also, the strengthened temperature stratification alone might exacerbate hypoxia (Rabalais et al. 2010). Changes in the coastal zones of the Baltic Sea due to high nutrient loads are region 
specific and manifested, for example, by increased occurrence of hypoxia, reduced nutrient retention, increased growth of opportunistic filamentous algae and drifting algae mats, and changes in species composition (Rönnberg and Bonsdorff 2004; Conley et al. 2011). Increased hypoxia also causes enhanced internal loads of dissolved inorganic phosphorus (DIP) and removal of dissolved inorganic nitrogen (DIN) which lead to lower N:P ratios and an increased potential for cyanobacteria blooms in the Baltic Sea (Vahtera et al. 2007). Exchanges of nutrients between sub-basins have been studied by Savchuk and Wulff (2007), but high-resolution studies of the transports that on longer time scales distribute the internal loads of nutrients to different parts of the Baltic Sea have not been discussed much before. The fate of river-borne nitrogen was followed by Neumann (2007), and Almroth Rosell et al. (2011) modeled long-term average transports of organic nutrients, but no general description of nutrient transports on time scales of changing climate (30 years) is available. We will therefore discuss transport patterns and regional variations of the internal nutrient loads in present climate and also how they are affected by future climate change and changes in external nutrient loads.

\section{Coastal and Open Sea Interactions}

The exposure of sediments to bottom stress from waves and currents has a great impact on the Baltic Sea scale. The transports of resuspended matter influence the distribution of sediment nutrient contents, bottom type distributions and also the oxygen demand in the deeper waters (Almroth Rosell et al. 2011). However, much of the resuspended matter and a large fraction of nitrogen supplied from land seem to be trapped in the coastal regions (Voss et al. 2005; Almroth Rosell et al. 2011), and denitrification seems to be an important nitrogen sink in the Baltic proper (Voss et al. 2011). In the present paper, we will investigate how the exchanges with the open sea may change in the projected future climate and discuss how the changes may affect the nutrient abatement in the coastal areas. The nutrients supplied from external sources that are not permanently removed or accumulated inside the Baltic proper will eventually become exported to the adjacent seas. Changes in nutrient transports between the Baltic proper and the adjacent seas will therefore also be discussed.

\section{MATERIALS AND METHODS}

\section{General Approach}

We calculated the long-term mean horizontal transport patterns in the high-resolution coupled physical- biogeochemical model RCO-SCOBI (Swedish Coastal and Ocean BIogeochemical model) of the Baltic Sea (Meier et al. 2003; Eilola et al. 2009). For practical reasons, the investigation was restricted to the Baltic proper as defined in (Fig. S1, Electronic supplementary material). Grid points with bottom depth less than $30 \mathrm{~m}$ were regarded as shallow and the net import of nutrients from the deeper Baltic proper to these shallow areas was quantified. By this definition, these shallow areas dynamically correspond to the areas having the most intensive impact from wave-induced sediment resuspension in the model (cf. Almroth Rosell et al. 2011). Grid points with bottom depth less than $10 \mathrm{~m}$ were regarded as very shallow. Similarly, the net import of nutrients to the Baltic proper from adjacent seas, the Gulf of Bothnia in the north and the Danish Sounds in the southwest, was computed. For comparison, we also summarized the external supplies of nutrients from land and atmosphere to the Baltic proper.

To produce maps showing the regional distributions of internal nutrient sources and sinks in the Baltic proper, we computed the net import to each cell of the horizontal model grid. Positive values indicate an import (sink), while negative values indicate an export of nutrients (source) from the grid cell. The sink of DIN and DIP is primary production and, in the case of DIN, also pelagic denitrification. Organic nutrients are removed by pelagic mineralization and net sedimentation. Pelagic mineralization and fluxes of inorganic nutrients from the sediments to the water are sources of DIN and DIP, while primary production and net resuspension are sources of organic nutrients.

The long-term (30-year) annual and seasonal average transports and imports of inorganic and organic nutrients were computed for the scenario period 2069-2098 (S3) and the control period 1978-2007 (C0) of a transient simulation 1961-2100. The mean changes were calculated from the differences between period $\mathrm{S} 3$ and $\mathrm{C} 0$.

Results were derived from RCO-SCOBI, forced with regionally down-scaled atmospheric forcing from two General Circulation Models (GCMs), HadCM3 from the Hadley Centre in the UK (Gordon et al. 2000) and ECHAM5 (ECHAM5/MPI-OM) from the Max Planck Institute for Meteorology in Germany (Roeckner et al. 2006, Jungclaus et al. 2006). Here, version r3 is used (see Meier et al. 2012a). The acronyms of the GCM models are used below to differentiate between RCO-SCOBI results derived with the two different forcing's. An evaluation of RCO-SCOBI results of the control period $\mathrm{C} 0$ is presented by Meier et al. (2012b). Observations of nutrient transports are not available. As the control climates from the GCMs constitute different realizations of present climate, the chronologies of observed and simulated weather differ. However, Meier et al. (2012b) showed that the statistics of 
observed and simulated physical and biogeochemical variables are in satisfactory agreement.

\section{Physical Model}

RCO is a Bryan-Cox-Semtner primitive equation circulation model with a free surface coupled to a Hibler-type sea ice model. A flux-corrected, monotonicity preserving transport (FCT) scheme is embedded. The resolution is $3.7 \mathrm{~km}$ in the horizontal and $3 \mathrm{~m}$ in the vertical, and the time step used in the present study was $75 \mathrm{~s}$. No explicit horizontal diffusion is applied and vertical diffusion is described by a $k-\varepsilon$ type turbulence closure scheme. The deep water mixing is assumed to be inversely proportional to the Brunt-Väisälä frequency. A bottom boundary layer model is embedded. Open boundary conditions are applied in the northern Kattegat. A simplified empirical wave model is included to calculate the combined effect of wave and current induced shear stress and thus the re-suspension of organic material. The 29 most important rivers are included which all together represent the total runoff to the Baltic Sea. For further details and references of the RCO model, see Meier (2007) and Meier et al. (2003).

\section{Biogeochemical Model}

SCOBI describes the dynamics of DIN (nitrate and ammonium) and DIP (phosphate), and particulate organic nitrogen $(\mathrm{OrgN})$ and phosphorus (OrgP) that include phytoplankton, zooplankton, and detritus. The nitrogen and phosphorus content of organic matter is described by the Redfield molar ratio ( $\mathrm{C}: \mathrm{N}: \mathrm{P}=106: 16: 1)$. Oxygen dynamics are included and hydrogen sulfide concentrations are represented by "negative oxygen" equivalents $\left(1 \mathrm{ml} \mathrm{H}_{2} \mathrm{~S}^{-1}=\right.$ $-2 \mathrm{ml} \mathrm{O}_{2} \mathrm{l}^{-1}$ ). Phytoplankton consists of three functional groups representing diatoms, flagellates and others, and cyanobacteria. The latter group has the ability to fix molecular nitrogen. Organic matter sinks and enters the sediment containing benthic nitrogen and phosphorus. The sediment processes include oxygen dependent nutrient regeneration and denitrification as well as burial of nutrients. Burial of nitrogen and phosphorus in the sediment and denitrification are the permanent nutrient sinks in the model. For further details, see Eilola et al. (2009, 2011) and Almroth Rosell et al. (2011).

\section{Regional Climate Forcing}

The scenario simulations were forced with the greenhouse gas emission scenario A1B from IPCCs Special Report on Emission Scenarios (SRES, Nakicenovic et al. 2000). Results from the regional climate model, Rossby Centre Atmosphere Ocean model (RCAO, see Döscher et al.
2002), with lateral boundary data from HadCM3 and ECHAM5 were used. No bias correction of the atmospheric forcing was applied, however, wind speed was modified using simulated gustiness (Höglund et al. 2009) to improve wind speed extremes (Meier et al. 2011c).

\section{Freshwater Supply}

The process oriented, hydrological model, HYdrological Predictions for the Environment (HYPE, see Lindström et al. 2010), driven with precipitation and air temperature fields from RCAO was used to calculate the volume flows of the 29 largest rivers (including adjacent coastal segments) for 1961-2100 (Arheimer et al. 2012).

\section{Nutrient Loading}

Nutrient loads from rivers were calculated from the product of the nutrient concentration and the volume flow following Stålnacke et al. (1999). Two scenarios were considered. Firstly, a reference scenario (REF) with current nutrient concentrations from rivers and point sources and current atmospheric deposition following Eilola et al. (2009) was performed. Secondly, a scenario with reduced nutrient concentrations following the Baltic Sea Action Plan (BSAP) (HELCOM 2007) and 50\% reduced atmospheric deposition was carried out. For details, see Gustafsson et al. (2011). In all scenario simulations, lateral boundary conditions in the Skagerrak were unchanged.

\section{Transports and Imports of Nutrients}

Transports of nutrients from one grid cell to another, vertically integrated from the sea floor to the sea surface (in ton $\mathrm{km}^{-1}$ month ${ }^{-1}$ ), were calculated during the model run from the horizontal fluxes between grid cells. The transports were accumulated in time and saved to file every second day. For each horizontal grid cell, the total net import of nutrients (ton $\mathrm{km}^{-2}$ month ${ }^{-1}$ ) from surrounding grid cells was then computed from the vertically integrated transports.

\section{Accumulated Import as Function of Bottom Depth}

The import of nutrients was summarized to all grid points shallower than a given bottom depth. By doing this for subsequently deeper and deeper areas in the Baltic proper, the integrated imports discretized with a depth resolution of $3 \mathrm{~m}$ given by the model was obtained. This accumulation method allows for an analysis of how the internal transports transfer nutrients between different depths within the Baltic proper. Note that the accumulated imports to all areas with a maximum depth less than $30 \mathrm{~m}$ then give the import to the shallow areas discussed above. The total accumulated net 
import of nutrients from adjacent seas to the Baltic proper is obtained when the import to all areas shallower than the maximum model bottom depth $(<250 \mathrm{~m})$ is integrated. For comparison, we also similarly summarized the external supplies of nutrients from land and atmosphere to all grid points shallower than a given bottom depth. Hence, the sum of supplies to areas shallower than the maximum depth of the model gives the total external supply of nutrients from land and atmosphere to the Baltic proper.

\section{Persistency}

The persistency $(R)$ of the net transports was defined similar to Andrejev et al. (2004), except that the ratio of the vector and scalar mean transports were computed instead of the current speeds (D1)

$R=\frac{\sqrt{\left(\frac{1}{N} \sum_{n} \mathrm{TU}_{n}\right)^{2}+\left(\frac{1}{N} \sum_{n} \mathrm{TV}_{n}\right)^{2}}}{\frac{1}{N} \sum_{n} \sqrt{\mathrm{TU}_{n}^{2}+\mathrm{TV}_{n}^{2}}} \times 100$

Here TU and TV are the eastward and northward transports, respectively. $N$ is the number of observations which in our case is the number of model results saved every second day during the 30-year period. The persistency is given in percent. If the net transport is unidirectional in time, $R$ equals $100 \%$, while $R$ becomes zero when the net transport is zero.

\section{Supplementing Guide to the Present Study of Transports and Imports}

For the discussions about transports and imports, one should bear in mind that the figures for OrgP are valid also for OrgN, only differing in magnitudes by the constant Redfield ratio. The relative changes in future projections are therefore equal for OrgN and OrgP. The organic nutrients in the model include only biologically active nutrients in phytoplankton, zooplankton, and dead organic matter. The background concentrations of more refractory dissolved organic nutrients assumed not bioavailable in the Baltic Sea, are comparably high especially for organic nitrogen (see e.g., Eilola 2009), but they are not included in the transports discussed here.

To clarify the relative importance of future changes in imports, these are weighted to corresponding total external supplies in the control period $\mathrm{C} 0$. The changes are shown in percent relative to the total external supply (\% rxs). To have a common reference also for the comparison of changes in spatial distributions of imports, the changes are calculated relative to the horizontal average of the total external supply (C0) to the Baltic proper (\% rhxs).

The presentation of results for the control period was mainly based on the HadCM3 case. The results differed mostly in the magnitudes of transports and imports that were larger in the ECHAM5 case because of slightly higher nutrient concentrations in the control period (cf. Meier et al. 2012b). Only the most significant differences between the cases are pointed out below.

\section{RESULTS AND DISCUSSION}

\section{Control Period Co}

The persistent patterns of the modeled long-term mean transports of nutrients agree with the large-scale internal water circulation of the Baltic Sea (BACC Author Team 2008, Fig. A7). However, for the vertically integrated transports discussed in this study, there are features that emerge due to the spatial and temporal variation of nutrient concentrations and the depth of the water column.

\section{Annual Mean DIP Transports}

The annual mean DIP transports are largest and most persistent in the deeper central parts of the Baltic proper (Fig. 1) because the DIP and DIN concentrations are normally highest in the deep waters (e.g., Eilola et al. 2011). The transports are also relatively large in other deep areas such as the Gdansk Bay, the Bornholm Basin and in the Gulf of Finland. There is a general cyclonic pattern with northward transports in the eastern and southward transports in the western parts of the central Baltic proper. Along the Swedish coast the transport is southward, except closer to the north-western coast of the Gotland island where a weak cyclonic circulation shows net northward transports. A major branch of the southward flow continues to the south and to the west along the Swedish coast, into the Bornholm Basin and further to the Arkona Basin. Another branch of the southward transport continues towards the Gdansk Bay in the southern Baltic proper. A persistent eastward flow from the southern and central Arkona Basin continues north of Bornholm through the central parts of the Bornholm Basin and turns southward towards the Gdansk Bay and joins the cyclonic circulation in the central Baltic proper. The Gulf of Finland and the Gulf of Riga show cyclonic circulation with inflows along the southern parts and outflows in the northern parts of the gulfs, respectively. A tendency towards cyclonic circulation patterns can also be noticed in the central parts of the Arkona Basin and the Bornholm Basin.

\section{Annual Mean DIN and Organic Nutrient Transports}

In contrast to DIP, relatively large transports of DIN can also be found in coastal areas in connection to the major 

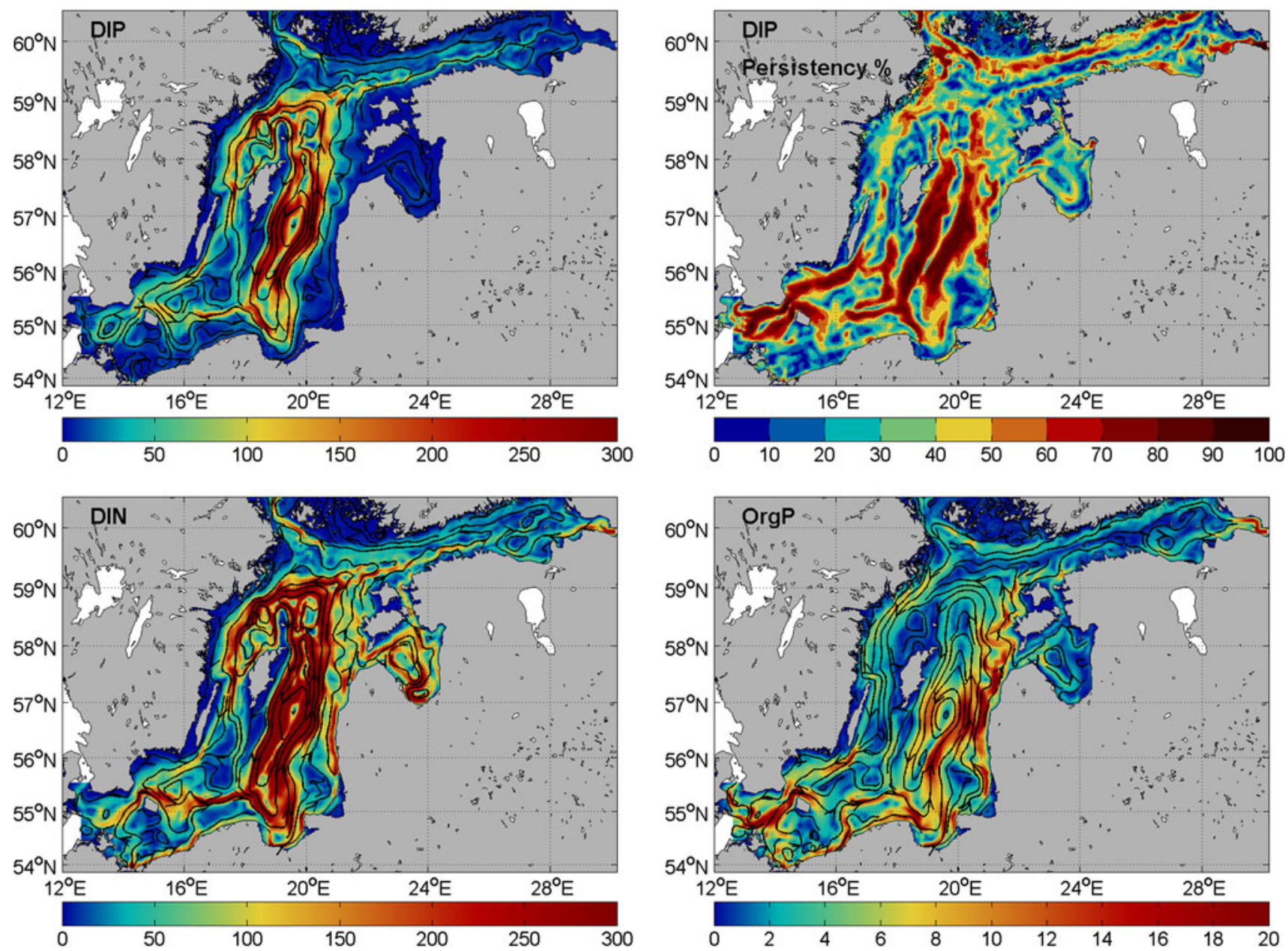

Fig. 1 HadCM3-REF control period annual average net DIP transport and corresponding persistency are shown in the upper left and right panels, respectively. The annual average net DIN and OrgP transports are shown in the lower left and right panels, respectively.

The black solid lines with arrows show the streamlines and direction of transports. The magnitude of transports (ton $\mathrm{km}^{-1}$ month $^{-1}$ ) and the persistency (\%) is shown by the background color. The corresponding values are shown in the lower color bars

rivers (cf. Eilola et al. 2011). This can also be noticed for the transports of organic nutrients (Fig. 1). Generally, the main transports of organic nutrients are found closer to the coast where much of the modeled primary production and biomass is found (cf. Meier et al. 2011a), and also the resuspension of organic nutrients from the sediments takes place (cf. Almroth Rosell et al. 2011).

\section{Seasonal Variations in Transports}

The seasonal net transport is largest in winter for all nutrients and smallest during summer as exemplified for OrgP in Fig. 2. Much of the variations are explained by the seasonal nutrient cycles as well as pelagic mineralization and sedimentation which cause declining transports of organic nutrients with increasing distance from the more productive coastal areas. The increased wind-wave driven sediment resuspension in autumn and winter causes increased transports of organic matter in shallow areas (Fig. 2).

The circulation in the northern parts of the Baltic proper seems mostly affected by seasonal dynamics. Here, the large accumulation of juvenile freshwater during spring and changed winds during summer (Eilola and Stigebrandt 1998; Hordoir and Meier 2010) cause changes in the transport patterns of nutrients. During winter and spring, the transports into the Gulf of Finland are larger than the outflow to the Baltic proper. In summer, the outflows from the Gulf of Finland start to dominate, and also the northward transports to the Bothnian Sea change to southward transports. The cyclonic transport pattern northwest of Gotland changes to anti-cyclonic, and for all nutrients, the southward transport takes place mainly along the western coast of Gotland in summer. In summer and autumn, the eastward component of the organic nutrient transports in the southern Baltic proper increases and the south-eastward 

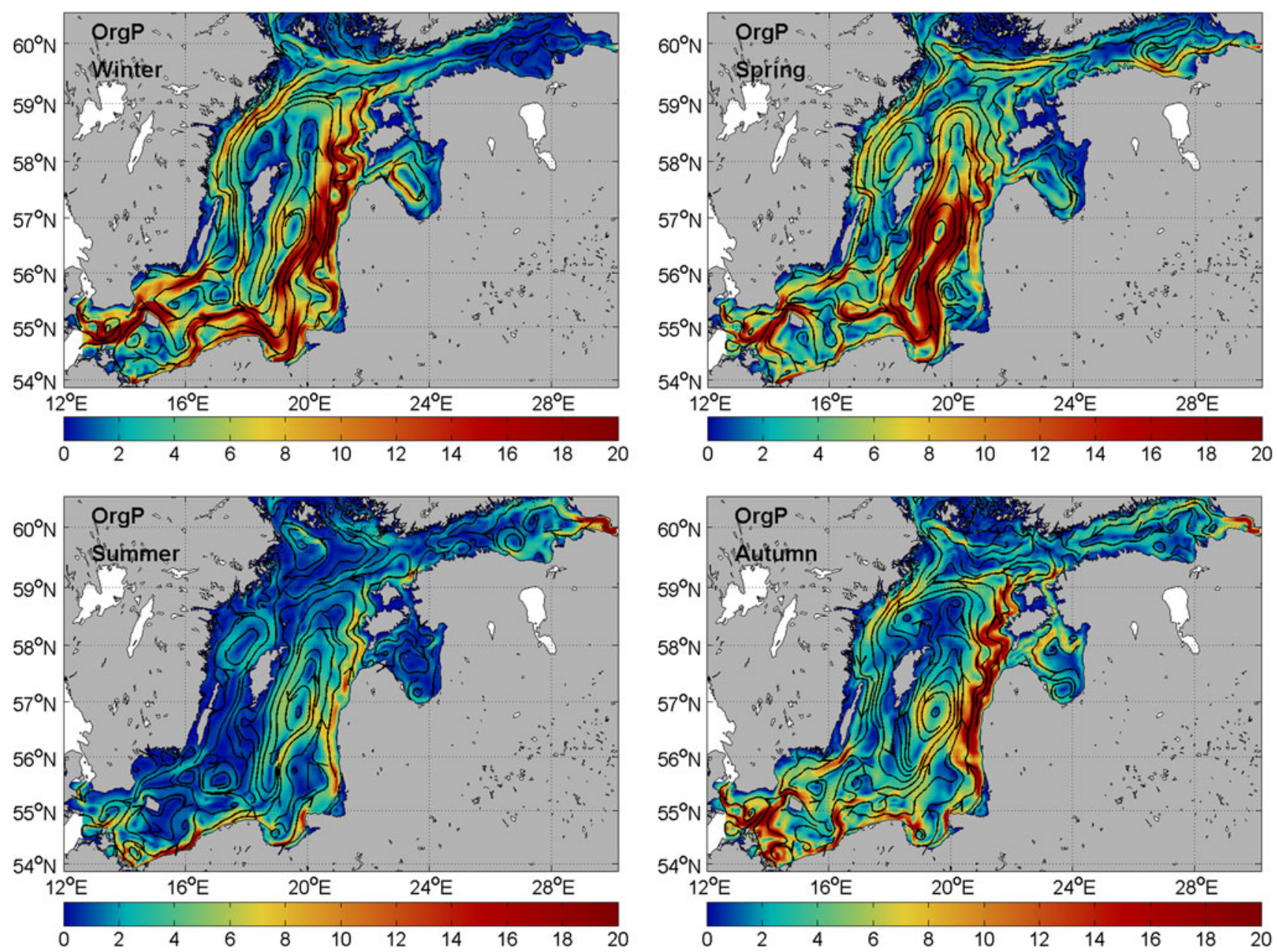

Fig. 2 HadCM3-REF control period seasonal average of winter (Dec-Feb), spring (Mar-May), summer (Jun-Aug), and autumn (Sep-Nov) net OrgP transports are shown in the upper left, upper right, and the lower left and right panels, respectively. The black solid

transports into the western parts of the Gdansk Bay are shifted to eastward and northward transports instead. During summer, inorganic nutrient concentrations are negligible in the surface layer which is why most DIN and DIP transports occur in deeper layers. This might explain why only the transports of organic nutrients, which take place mostly in the surface layers, may show changes in direction in the southern Baltic proper during summer.

\section{Imports from Adjacent Seas and External Supplies}

The net DIP export to the adjacent seas is about 50 and $75 \%$ of the total external supply of DIP to the Baltic proper for HADCM3 and ECHAM5 cases, respectively (Table 1). For DIN, the total external supply from land and atmosphere is generally accumulated or lost in the internal sink of the Baltic proper. Organic phosphorus and nitrogen are supplied to the Baltic proper from external sources and

lines with arrows show the streamlines and direction of transports. The magnitude of transports (ton $\mathrm{km}^{-1}$ month $^{-1}$ ) is shown by the background color with the corresponding values shown in the lower color bars

a minor portion from adjacent seas. There is also an additional source of nitrogen from $\mathrm{N}$-fixation by cyanobacteria (not shown), which is balanced by the internal nitrogen sink in the model. The budget model by Savchuk and Wulff (2007) indicated that about 60 and $10 \%$ of the total external phosphorus and nitrogen supplies (1997-2003), respectively, were exported from the Baltic proper. However, the numbers are not comparable with the present study because, in addition to the differing time periods, their total transports included also nutrients regarded as not bioavailable.

\section{Depth Dependence of External Supplies}

The rapid increase with depth of accumulated external nutrient supplies (Fig. S2, Electronic supplementary material) demonstrate that the largest inputs of nutrients take place in the very shallow areas with a maximum 
Table 1 The total external supplies from land and atmosphere to the entire Baltic proper and to areas shallower than $30 \mathrm{~m}$ are shown in rows $\mathrm{A}$ and $\mathrm{B}$, respectively. The import from adjacent seas to the
Baltic proper is shown in row $\mathrm{C}$. The import from deeper parts of the Baltic proper to areas shallower than $30 \mathrm{~m}$ is shown in row D

\begin{tabular}{|c|c|c|c|c|c|c|c|c|}
\hline & $\begin{array}{l}\text { HadCM3 } \\
\text { OrgP }\end{array}$ & $\begin{array}{l}\text { ECHAM5 } \\
\text { OrgP }\end{array}$ & $\begin{array}{l}\text { HadCM3 } \\
\text { DIP }\end{array}$ & $\begin{array}{l}\text { ECHAM5 } \\
\text { DIP }\end{array}$ & $\begin{array}{l}\text { HadCM3 } \\
\text { OrgN }\end{array}$ & $\begin{array}{l}\text { ECHAM5 } \\
\text { OrgN }\end{array}$ & $\begin{array}{l}\text { HadCM3 } \\
\text { DIN }\end{array}$ & $\begin{array}{l}\text { ECHAM5 } \\
\text { DIN }\end{array}$ \\
\hline \multicolumn{9}{|c|}{ Control period $\mathrm{C} 0$} \\
\hline A & 1.0 & 0.9 & 1.2 & 1.2 & 6.9 & 6.8 & 42.9 & 42.7 \\
\hline B & 1.0 & 0.9 & 1.0 & 1.0 & 6.9 & 6.8 & 31.9 & 31.6 \\
\hline $\mathrm{C}$ & 0.2 & 0.2 & -0.6 & -0.9 & 1.2 & 1.1 & -0.2 & -0.1 \\
\hline $\mathrm{D}$ & -2.6 & -3.2 & 1.0 & 1.5 & -18.7 & -22.9 & -11.3 & -9.7 \\
\hline \multicolumn{9}{|c|}{ REF Scenario S3 } \\
\hline A & 0.9 & 1.0 & 1.1 & 1.2 & 6.5 & 7.0 & 41.4 & 43.4 \\
\hline B & 0.9 & 1.0 & 0.9 & 1.0 & 6.5 & 7.0 & 30.3 & 32.3 \\
\hline $\mathrm{C}$ & 0.1 & 0.1 & -1.1 & -1.2 & 0.9 & 0.9 & -0.2 & -0.5 \\
\hline $\mathrm{D}$ & -3.0 & -3.6 & 1.5 & 1.9 & -21.8 & -26.2 & -9.2 & -9.0 \\
\hline \multicolumn{9}{|c|}{ BSAP Scenario S3 } \\
\hline A & 0.5 & 0.5 & 0.7 & 0.8 & 3.6 & 3.8 & 28.5 & 30.0 \\
\hline B & 0.5 & 0.5 & 0.5 & 0.6 & 3.6 & 3.8 & 22.9 & 24.4 \\
\hline $\mathrm{C}$ & 0.2 & 0.2 & -0.5 & -0.6 & 1.1 & 1.2 & -0.1 & 0.0 \\
\hline D & -2.1 & -2.5 & 1.3 & 1.6 & -15.3 & -18.0 & -5.6 & -5.6 \\
\hline
\end{tabular}

Results $\left(10^{3}\right.$ ton month $\left.^{-1}\right)$ for OrgP, DIP, OrgN, and DIN are shown for the HadCM3 and ECHAM5 cases in the control period C0 and in the projected REF and BSAP scenarios. Negative numbers are interpreted as an export

bottom depth of less than about $10 \mathrm{~m}$ in the model. This is due to the supplies from land that include all external supplies of organic nutrients, 83 and $74 \%$, respectively, of the total external supplies of DIP and DIN (Table 1). There is also an atmospheric deposition of DIN and DIP that causes a continuous increase with depth when consecutively deeper areas are added to the accumulated supply.

\section{Depth Dependence of Internal Imports}

The import of DIP to areas shallower than $30 \mathrm{~m}$ is substantial and of the same order of magnitude or larger as the external supply (Fig. 3). This internal supply of DIP fuels the productivity in the shallow regions, and the export of OrgP from shallow areas is even larger than the external supply of total phosphorus to the entire Baltic proper (Table 1). The net export of DIN and DIP from the very shallow areas is less than the corresponding external supply (Fig. S2, Electronic supplementary material) because the high productivity in these regions effectively transfers DIN and DIP to OrgN and OrgP, respectively. Eventually about 25-30 \% of the total nitrogen supply to the shallow areas becomes exported as DIN, while $50-60 \%$ is exported as OrgN to the deeper areas (Fig. 3). The rest is accumulated and/or denitrified in the shallow areas. However, the accumulated exports of inorganic and organic nitrogen (Fig. S2, Electronic supplementary material) decline rapidly with increasing bottom depth, and only a minor fraction of the nitrogen supplied to the shallower areas reaches areas deeper than $100 \mathrm{~m}$ in the Baltic proper. These results are in agreement with the studies by Voss et al. (2005) and Almroth Rosell et al. (2011) which both indicate that much of the inputs from land are trapped along the coastal rim of the Baltic proper.

\section{Spatial Distributions of Internal Imports}

The internal recycling of phosphorus illustrated in Fig. 4 shows that areas importing OrgP generally export DIP, while the export areas for OrgP show an import of DIP. Also the shallow areas having the largest imports of DIN correspond well with areas having large exports of organic nutrients and large imports of DIP. The largest exports of DIP occur at intermediate depths between about 60 and $100 \mathrm{~m}$, while exports from deeper areas are relatively smaller (cf. Fig. S2, Electronic supplementary material). This corresponds with the separation between Group 1 and Group 2 type of sediment sampling stations according to Mort et al. (2010) and Jilbert et al. (2011). They defined depths shallower than $90 \mathrm{~m}$ as oxic-seasonally anoxic and deeper areas as semi-permanently hypoxic-anoxic. Jilbert et al. (2011) did not find any clear trend with water depth in sediment DIP fluxes. It is, however, difficult to draw any further conclusions about long term mean fluxes comparable to the present results from a set of data collected at discrete times and places. 


\section{External supplies to shallow areas}

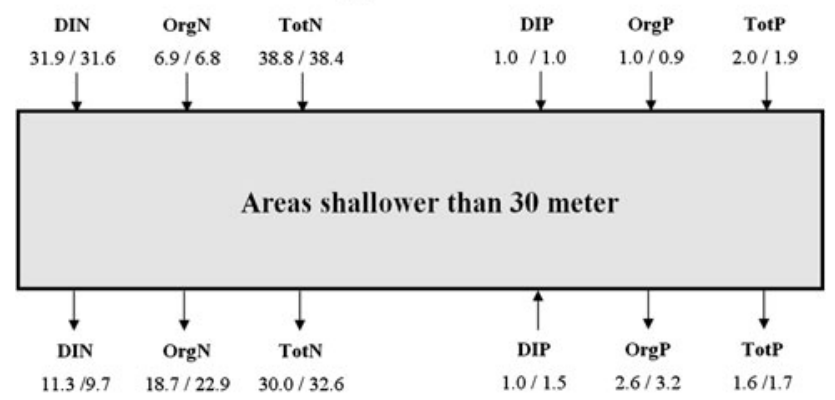

Deeper areas

Fig. 3 The total external supplies of DIN, OrgN, TotN, DIP, OrgP, and TotP from land and atmosphere in the control period (HadCM3C0/ECHAM5-C0), to the areas shallower than $30 \mathrm{~m}$ are shown above the gray box (c.f. Table 1). The corresponding internal imports from deeper parts of the Baltic proper to areas shallower than $30 \mathrm{~m}$ are shown below the box. Arrows pointing out from the box indicate negative import, i.e., an export to deeper areas
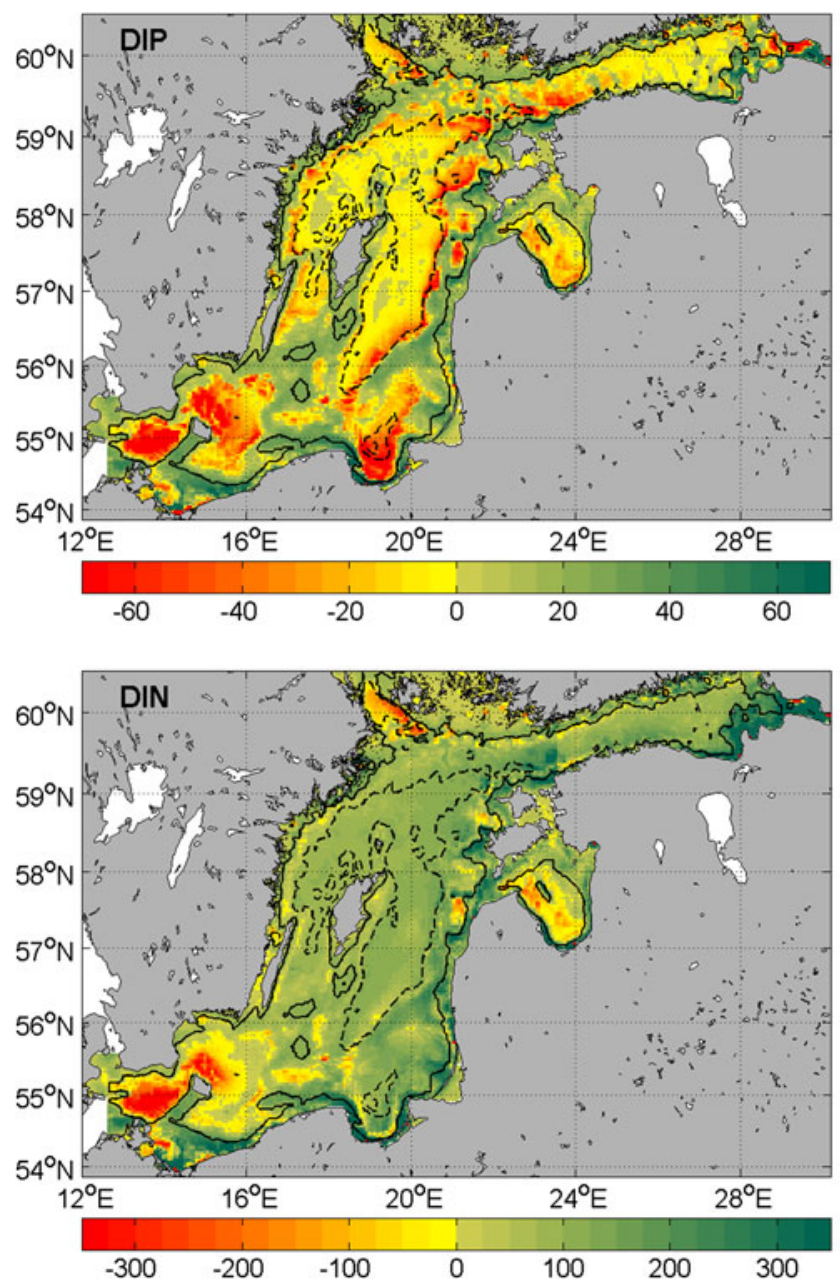

Fig. 4 HadCM3-REF control period, spatial distribution of annual average import of nutrients. Imports of DIP and OrgP are shown in the upper left and right columns, respectively. DIN and OrgN are shown below. The black solid and dashed lines show 30 and $100 \mathrm{~m}$ depth contours of the model. The magnitude of import
More detailed studies using RCO-SCOBI, following the ideas of Reed et al. (2011), who used a coupled benthicpelagic reactive-transport model to study oxygen and phosphorus dynamics in the Arkona Basin, may clarify the processes involved.

The difference in the functionality of DIN and DIP sinks becomes obvious in the Eastern Gotland Deep where there is an annual average import of DIN but a net export of DIP (Fig. 4). This difference is due to denitrification and nutrient retention in the sediments, which increase the removal of DIN and reduce the removal of DIP, respectively, when oxygen concentrations become low (hypoxic) (e.g., Savchuk 2010). On an annual basis, mainly the Arkona Basin, parts of the Bornholm Basin and the Gulf of Riga show significant exports of DIN and DIP. With few exceptions, the rest of the area is generally importing DIN with largest imports found along the coasts.


(ton $\mathrm{km}^{-2}$ month ${ }^{-1}$ ) is shown by the background color with the corresponding values shown in the lower color bar. Green color denotes positive values (import) and yellow to red colors denote negative values (export) 

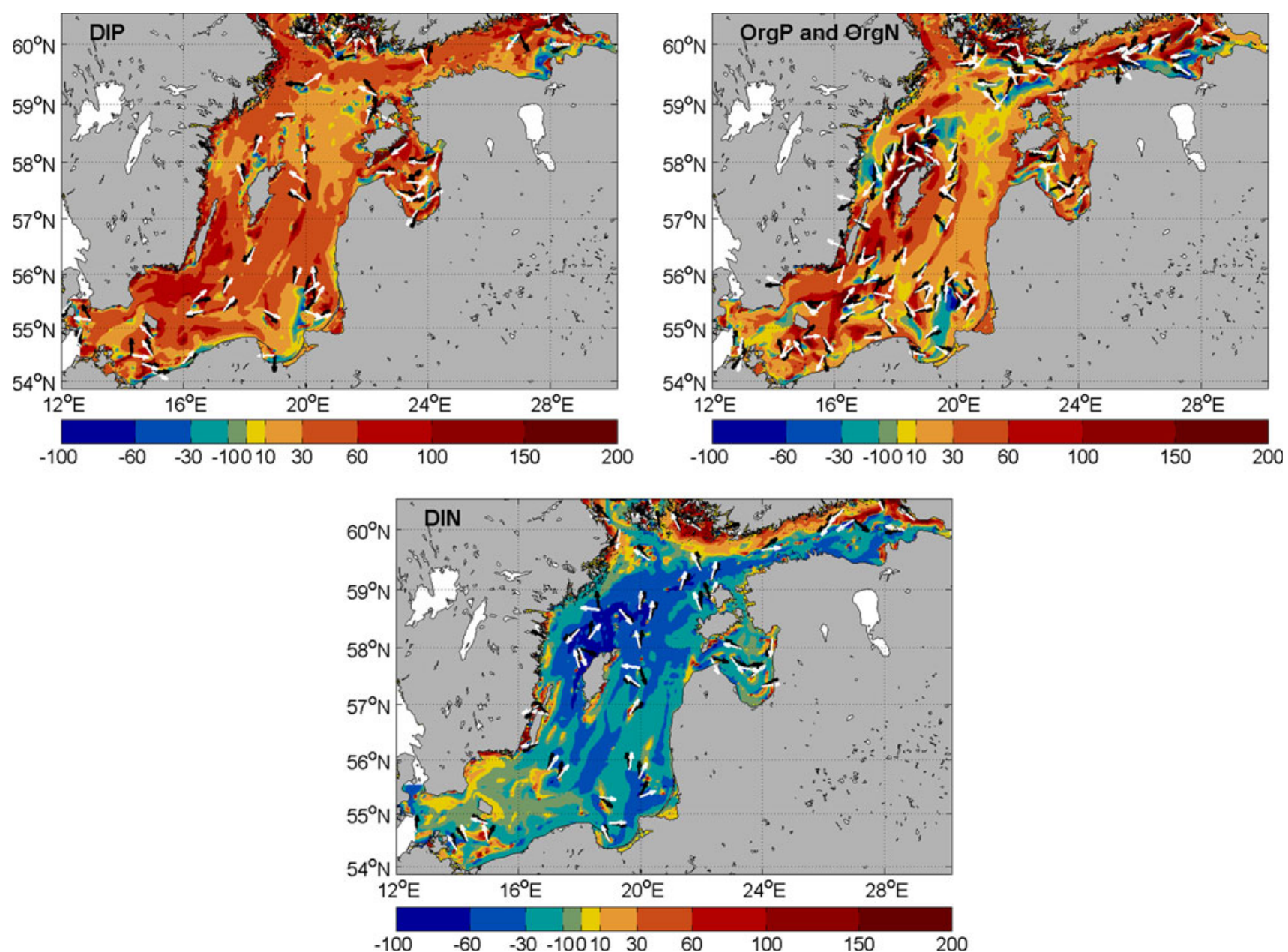

Fig. 5 Relative changes (\%) between periods S3 and C0 of annual mean transports of DIP and OrgP/OrgN are shown in the upper left and right columns, respectively. DIN is shown below. The change in

\section{Future Climate Scenario S3}

In climate projections, transports show only small changes in their directions (Fig. 5). Because of the large regional variations in the magnitude of transports (cf. Fig. 1), it is hard to compare the changes in absolute numbers. The changes in Fig. 5 are therefore shown relative to the transports in the control period. The transports of DIP and OrgP increase in REF (Fig. 5). Some reduced DIP transports are also noticed, e.g., in the south-eastern part of the Gulf of Finland and the Gulf of Gdansk (Fig. 5). Generally, the DIN transports decrease according to HadCM3-REF. However, significant increases occur in the northern parts of the Gulf of Finland and in some smaller areas in the southern Baltic proper (Fig. 5). In ECHAM5-REF, DIN transports increase also in the Arkona and Bornholm basins, along the southern coasts and in the eastern parts of the Baltic proper (not shown). case of HadCM3-REF is shown and the change of direction is given by the difference between the white $(\mathrm{S} 3)$ and the black $(\mathrm{C} 0)$ arrows (only shown if direction changed more than $10^{\circ}$ )

Nutrient transports in BSAP are generally slightly reduced but areas with increased transports are also found, e.g., in the deep parts of the Gulf of Finland, the Bornholm Basin and the north-western Baltic proper (not shown). In ECHAM5-BSAP, DIN transports increase in all deep areas surrounding Gotland.

\section{The Reference Scenario}

The total external supply of nutrients decreases in HadCM3-REF (4-6\% rxs) while there is a small increase in ECHAM5-REF (2-3\% rxs) (Table 1). The difference is due to the changes of freshwater runoff which decreases in HadCM3 and increases in ECHAM5 (Meier et al. 2012a). The export to adjacent seas increases, and all DIP supplied from land and atmosphere to the Baltic proper becomes exported to adjacent seas (Table 1). The import of organic nutrients from adjacent seas is slightly reduced while the 

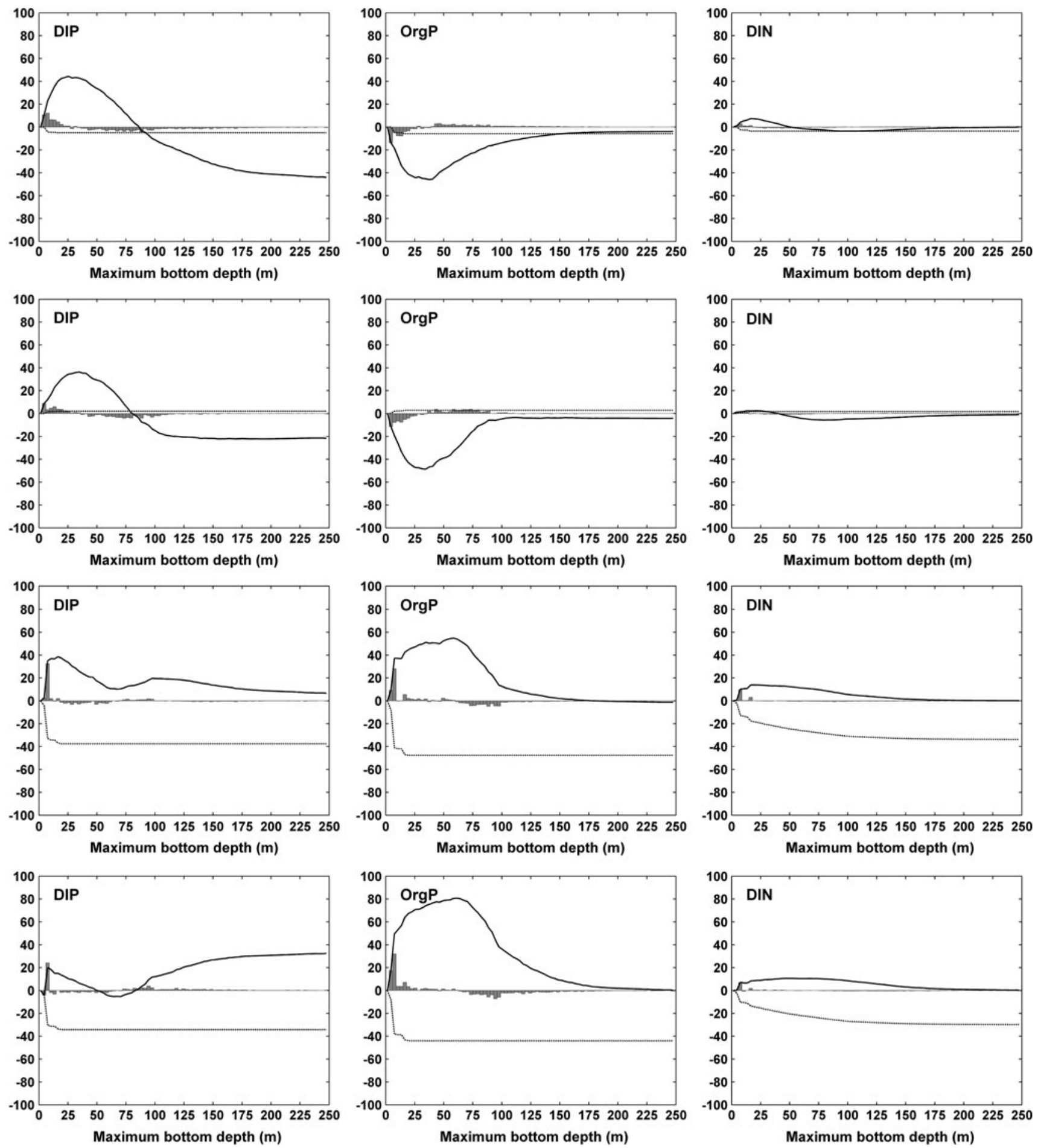

Fig. 6 Relative changes (\% rxs) between periods S3 and C0 of annual average net imports of DIP, OrgP, and DIN to regions with the same depth in the Baltic proper (gray bars) are shown in the left, middle, and right columns, respectively. The changes in cases HadCM3-REF (row 1), ECHAM5-REF (row 2), HadCM3-BSAP (row 3), and ECHAM5-BSAP (row 4) are shown. The corresponding changes in the accumulated imports and the external supplies of nutrients from land and atmosphere are shown by the solid line and the dash-dotted lines, respectively. Note: In each case, $100 \%$ rxs correspond to a change equal in magnitude to the actual nutrient supply given in row A of the control period in Table 1. The relative changes of $\operatorname{OrgN}$ and $\operatorname{OrgP}$ are equal 

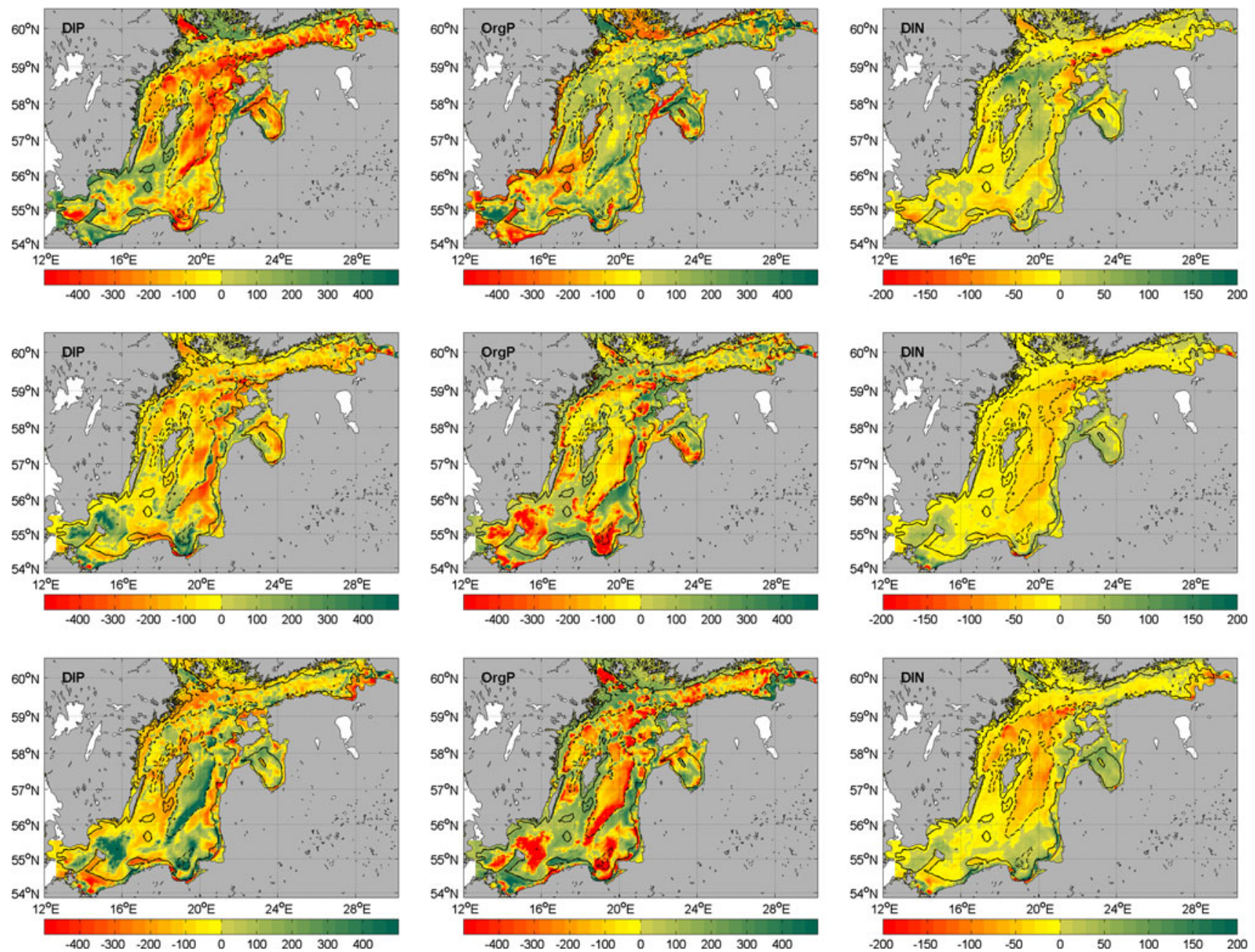

Fig. 7 The spatial distribution of relative changes (\% rhxs) between periods $\mathrm{S} 3$ and $\mathrm{C} 0$ of annual average net imports of DIP, OrgP, and DIN are shown in the left, middle, and right columns, respectively. The changes in cases HadCM3-REF (row 1), HadCM3-BSAP (row 2), and ECHAM5-BSAP (row 3) are shown. Note: In each case,

import of DIN is relatively unchanged (cf. Fig. 6). Both the net import of inorganic nutrients to the areas shallower than $30 \mathrm{~m}$ and the export of organic nutrients from the shallow areas do increase (Fig. 6; Table 1). The results are especially pronounced for the import of DIP that shows an increase comparable to about $40 \%$ rxs of DIP to the Baltic proper. Also, the exports of DIP from deeper areas, and the imports of DIN and organic nutrients to the deeper areas are increased (Fig. 7). The intensified exchange between the shallower and deeper areas observed here can be explained by the intensified nutrient cycling in a warmer climate as described, e.g., by Meier et al. (2012a). During intervals of increased hypoxia and intensified phosphorus cycling, Jilbert et al. (2011) found that the net burial rate of organic P increased around the margins of the deep basins. The results of the present model study suggest, however, that the net burial of phosphorus in a warmer climate
$100 \%$ rhxs correspond to a change equal in magnitude to the horizontal average of the actual nutrient supply given in row A of the control period in Table 1. The area of the modeled Baltic proper defined in Fig. S1, Electronic supplementary material is $263000 \mathrm{~km}^{2}$. The relative changes of OrgN and OrgP are equal

becomes less effective in the Baltic proper due to intensified nutrient cycling. The field studies by Jilbert et al. (2011) further suggest that preferential phosphorus mineralization with respect to carbon, may be a key player besides the mineral bound redox dependent phosphorus dynamics. However, with the present model setup this effect cannot be investigated.

\section{The Baltic Sea Action Plan Scenario}

As a consequence of reduced loads (30-48\% rxs) (Table 1), the export of DIP decreases from the very shallow areas where nutrients are supplied (Fig. 6), and also the export of DIP to adjacent seas is reduced (Table 1). However, since the imports from the deeper parts of the sea are not reduced as much as the supplies from land and atmosphere, the net effect is actually an increased net 
import of DIP to areas shallower than $30 \mathrm{~m}$. Because of the large contribution from the internal nutrient loading, the productivity sustains a relatively high export of organic nutrients from the shallow areas. The OrgP export decreases only by about $20 \%$ while the external phosphorus supplies to shallow areas are reduced by more than $40 \%$ (Table 1). Also the efficiency of DIN removal is enhanced and the DIN exports decreases more than $40 \%$, whereas external DIN supplies to the shallow areas are reduced by only $23-28 \%$.

There are differences in the relative responses of HadCM3-BSAP and ECHAM5-BSAP, but these are mainly due to differences in the magnitudes of changes. The only obvious opposing result is found in the areas deeper than about $100 \mathrm{~m}$, where HadCM3-BSAP shows increased exports of DIP, while ECHAM5-BSAP shows decreased exports (Fig. 7). It was found by Meier et al. (2012b) that bottom water oxygen concentrations in the ECHAM5BSAP case were improved in the deeper areas of the Gotland Basin, while there were no improvements in the HadCM3-BSAP. Hence, as the phosphorus release capacity of the sediments decreases with increased oxygen concentrations, it may explain why in ECHAM5-BSAP also the export of DIP may decrease. There are also differences in the responses to BSAP found in other locations as well, and Meier et al. (2012b) concluded that the different responses in bottom oxygen conditions between HadCM3BSAP and ECHAM5-BSAP influenced also the relative changes of surface layer nutrient concentrations, e.g., in the Gulf of Finland.

\section{CONCLUSION}

The results of this study suggest that during the control period, the import of DIP from deeper to shallower areas is substantial and comparable to the entire supply of DIP from land and atmosphere to the Baltic proper. The internal removal of nitrogen balances the supplies while phosphorus is exported to adjacent seas.

The transports of nutrients in the Baltic Sea follow to a large extent the general water circulation. However, the relative size of the transports of different forms of nutrients varies spatially due to characteristics of their sources and sinks. Changes in the general transport patterns in the future scenarios are small.

We found that the internal removal of phosphorus is much reduced in the reference scenario and all DIP supplied to the Baltic proper is exported to adjacent seas. DIP import to shallow areas is substantially enhanced and the export of organic nitrogen and phosphorus from shallow to deeper areas is increased.
The intensified internal nutrient cycling and the reduced internal removal of phosphorus counteract the impact from nutrient reductions according to BSAP and the net effect of climate change and nutrient load reductions is actually an increased import of DIP to areas shallower than $30 \mathrm{~m}$.

Despite differences between the projections based on HadCM3 and ECHAM5, the main message from both simulations is generally the same. The results from the present study have implications for the nutrient load reductions needed to combat increasing eutrophication in the Baltic Sea and emphasize that future climate changes should be taken into account in the BSAP revision process.

In this study, we focused on results from a limited ensemble of future scenarios to highlight some processes affected by climate change. Other studies have used multimodel ensembles and a wider range of future scenarios to quantify uncertainties of projections (e.g., Meier et al. 2011b). We conclude that there is a need for better understanding of temperature-dependent biogeochemical processes and their interactions in the Baltic Sea. Also, the fate of the increased export of phosphorus to adjacent seas needs to be further studied. Further detailed investigations about processes in the coastal zone, such as upwelling events, sediment resuspension, and vertical transports of nutrients in different regions, are recommended.

Acknowledgments The research presented in this study is part of the projects Assessment and Modeling Baltic Ecosystem Response (AMBER) and Advanced modeling tool for scenarios of the Baltic Sea ECOsystem to SUPPORT decision making (ECOSUPPORT) and has received funding from the European Community's Seventh Framework Programme (FP/2007-2013) under Grant Agreement No. 217246 made with BONUS, the joint Baltic Sea research and development program and from the Swedish Environmental Protection Agency (SEPA, ref. nos. 08/390 and 08/381). The RCO-SCOBI model simulations were partly performed on the climate computing resources 'Ekman' and 'Vagn' that are operated by the National Supercomputer Centre (NSC) at Linköping University and the Centre for High Performance Computing (PDC) at the Royal Institute of Technology in Stockholm, respectively. These computing resources are funded by a grant from the Knut and Alice Wallenberg Foundation.

\section{REFERENCES}

Almroth Rosell, E., K. Eilola, R. Hordoir, H.E.M. Meier, and P. Hall. 2011. Transport of fresh and resuspended particulate organic material in the Baltic Sea-A model study. Journal of Marine Systems 87: 1-12.

Andrejev, O., K. Myrberg, P. Alenius, and P. Lundberg. 2004. Mean circulation and water exchange in the Gulf of Finland-A model study based on three-dimensional modeling. Boreal Environment Research 9: 1-16.

Arheimer, B., J. Dahné, and C. Donnelly. 2012. Climate change impact on riverine nutrient load and land-based remedial measures of the Baltic Sea action plan? AMBIO. doi: 10.1007/s13280-012-0323-0. 
BACC Author Team. 2008. Assessment of climate change for the Baltic Sea Basin. Regional Climate Studies. Berlin: Springer.

Conley, D.J., J. Carstensen, J. Aigars, P. Axe, E. Bonsdorff, T. Eremina, B.-M. Haahti, C. Humborg, et al. 2011. Hypoxia is increasing in the coastal zone of the Baltic Sea. Environmental Science and Technology 45: 6777-6783.

Döscher, R., U. Willén, C. Jones, A. Rutgersson, H.E.M. Meier, U. Hansson, and L.P. Graham. 2002. The development of the regional coupled ocean-atmosphere model RCAO. Boreal Environment Research 7: 183-192.

Eilola, K. 2009. On the dynamics of organic nutrients, nitrogen and phosphorus, in the Baltic Sea. SMHI Reports Oceanography No. 99.

Eilola, K., and A. Stigebrandt. 1998. Spreading of juvenile freshwater in the Baltic proper. Journal of Geophysical Research 103: 27795-27807.

Eilola, K., H.E.M. Meier, and E. Almroth. 2009. On the dynamics of oxygen, phosphorus and cyanobacteria in the Baltic Sea: A model study. Journal of Marine Systems 75: 163-184.

Eilola, K., B.G. Gustafson, I. Kuznetsov, H.E.M. Meier, and O.P. Savchuk. 2011. Evaluation of biogeochemical cycles in an ensemble of three state-of-the-art numerical models of the Baltic Sea. Journal of Marine Systems 88: 267-284.

Gordon, C., C. Cooper, C.A. Senior, H. Banks, J.M. Gregory, T.C. Johns, J.F.B. Mitchell, and R.A. Wood. 2000. The simulation of SST, sea ice extent and ocean heat transports in a version of the Hadley Centre coupled model without flux adjustments. Climate Dynamics 16: 147-166.

Gustafsson, B.G., O.P. Savchuk, and H.E.M. Meier. 2011. Load scenarios for ECOSUPPORT. Technical Report 4. Stockholm: Baltic Nest Institute. ISSN 978-91-86655-03-7.

Gustafsson, B.G., F. Schenk, T. Blenckner, K. Eilola, H.E.M. Meier, B. Müller-Karulis, T. Neumann, T. Ruoho-Airola, et al. 2012. Reconstructing the development of Baltic Sea eutrophication 1850-2006. AMBIO. doi:10.1007/s13280-012-0318-x.

HELCOM. 2007. Toward a Baltic Sea unaffected by eutrophication. Background document to Helcom Ministerial Meeting, Krakow, Poland, Tech. rep., Helsinki Commission, Helsinki, Finland.

Höglund, A., H.E.M. Meier, B. Broman, and E. Kriezi. 2009. Validation and correction of regionalised ERA-40 wind fields over the Baltic Sea using the Rossby Centre Atmosphere model RCA3.0. Rapport Oceanografi No. 97. Norrköping: SMHI.

Hordoir, R., and H.E.M. Meier. 2010. Freshwater fluxes in the Baltic Sea: A model study. Journal of Geophysical Research 115: C08028-1-C08028-14. doi:10.1029/2009JC005604.

Jilbert, T., C.P. Slomp, B.G. Gustafsson, and W. Boer. 2011. Beyond the Fe-P-redox connection: Preferential regeneration of phosphorus from organic matter as a key control on Baltic Sea nutrient cycles. Biogeosciences 8: 1699-1720.

Jungclaus, J.H., M. Botzet, H. Haak, N. Keenlyside, J.J. Luo, M. Latif, J. Marotzke, U. Mikolajewicz, et al. 2006. Ocean circulation and tropical variability in the coupled ECHAM5/ MPI-OM. Journal of Climate 19: 3952-3972.

Leppäranta, M., and K. Myrberg. 2009. Physical oceanography of the Baltic Sea. Chichester: Praxis Publishing Ltd. ISBN 978-3-54079702-9.

Lindström, G., C. Pers, J. Rosenberg, J. Strömqvist, and B. Arheimer. 2010. Development and testing of the HYPE (Hydrological Predictions for the Environment) water quality model for different spatial scales. Hydrology Research 41: 295-319.

Meier, H.E.M. 2007. Modeling the pathways and ages of inflowing salt- and freshwater in the Baltic Sea. Estuarine, Coastal and Shelf Science 74: 610-627.

Meier, H.E.M., R. Döscher, and T. Faxén. 2003. A multiprocessor coupled ice-ocean model for the Baltic Sea: Application to salt inflow. Journal of Geophysical Research 108: 3273. doi: 10.1029/2000JC000521.
Meier, H.E.M., K. Eilola, and E. Almroth. 2011a. Climate-related changes in marine ecosystems simulated with a three-dimensional coupled biogeochemical-physical model of the Baltic Sea. Climate Research 48: 31-55.

Meier, H.E.M., H.C. Andersson, K. Eilola, B. Gustafsson, I. Kuznetsov, B. Müller-Karulis, T. Neumann, and O.P. Savchuk. 2011b. Hypoxia in future climates-a model ensemble study for the Baltic Sea. Geophysical Research Letters 38: L24608. doi: 10.1029/2011GL049929.

Meier, H.E.M., A. Höglund, R. Döscher, H. Andersson, U. Löptien, and E. Kjellström. 2011c. Quality assessment of atmospheric surface fields over the Baltic Sea of an ensemble of regional climate model simulations with respect to ocean dynamics. Oceanologia 53: 193-227.

Meier, H.E.M., B. Müller-Karulis, H.C. Andersson, C. Dieterich, K. Eilola, B.G. Gustafsson, A. Höglund, R. Hordoir, et al. 2012a. Impact of climate change on biogeochemical cycles in the Baltic Sea-A multi-model ensemble study. AMBIO. doi:10.1007/ s13280-012-0320-3.

Meier, H.E.M., H.C. Andersson, C. Dieterich, K. Eilola, B.G. Gustafsson, A. Höglund, R. Hordoir, and S. Schimanke. 2012b. Modeling the combined impact of changing climate and changing nutrient loads on the Baltic Sea environment in an ensemble of transient simulations for 1961-2099. Climate Dynamics, Earth and Environmental Science. doi:10.1007/ s00382-012-1339-7.

Mort, H.P., C.P. Slomp, B.G. Gustafsson, and T.J. Andersen. 2010. Phosphorus recycling and burial in Baltic Sea sediments with contrasting redox conditions. Geochimica et Cosmochimica Acta 74: $1350-1362$.

Nakicenovic, N., J. Alcamo, G. Davis, B. de Vries, J. Fenhann, S. Gaffin, K. Gregory, A. Grübler, et al. 2000. IPCC Special Report on Emissions Scenarios. Cambridge: Cambridge University Press.

Neumann, T. 2007. The fate of river-borne nitrogen in the Baltic Sea-An example for the River Oder. Estuarine, Coastal and Shelf Science 73: 1-7.

Neumann, T. 2011. Climate-change effects on the Baltic Sea ecosystem: A model study. Journal of Marine Systems 8: 213-224

Philippart, C.J.M., R. Anadón, R. Danovaro, J.W. Dippner, K.F. Drinkwater, S.J. Hawkins, T. Oguz, G. O'Sullivan, et al. 2011. Impacts of climate change on European marine ecosystems: Observations, expectations and indicators. Journal of Experimental Marine Biology and Ecology 400: 52-69.

Rabalais, N.N., R.J. Díaz, L.A. Levin, R.E. Turner, D. Gilbert, and J. Zhang. 2010. Dynamics and distribution of natural and humancaused hypoxia. Biogeosciences 7: 585-619.

Reed, D.C., C.P. Slomp, and B.G. Gustafsson. 2011. Sedimentary phosphorus dynamics and the evolution of bottom-water hypoxia: A coupled benthic-pelagic model of a coastal system. Limnology and Oceanography 56: 1075-1092.

Roeckner, E., R. Brokopf, M. Esch, M. Giorgetta, S. Hagemann, L. Kornblueh, E. Manzini, U. Schlese, et al. 2006. Sensitivity of simulated climate to horizontal and vertical resolution in the ECHAM5 atmosphere model. Journal of Climate 19: 3771-3791.

Rönnberg, C., and E. Bonsdorff. 2004. Baltic Sea eutrophication: area-specific ecological consequences. Hydrobiologia 514: 227-241.

Savchuk, O.P. 2010. Large-scale dynamics of hypoxia in the Baltic Sea. In Chemical structure of pelagic redox interfaces: Observation and modeling, $\mathrm{Hdb}$ Env Chem, ed. E.V. Yakushev. Berlin: Springer. doi:10.1007/698_2010_53.

Savchuk, O.P., and F. Wulff. 2007. Modeling the Baltic Sea eutrophication in a decision support system. AMBIO 36: 141-148.

Stålnacke, P., A. Grimvall, K. Sundblad, and A. Tonderski. 1999. Estimation of riverine loads of nitrogen and phosphorus to the 
Baltic Sea 1970-1993. Environmental Monitoring and Assessment 58: 173-200.

Vahtera, E., D. Conley, B.G. Gustafsson, H. Kuosa, H. Pitkänen, O.P. Savchuk, T. Tamminen, M. Viitasalo, et al. 2007. Internal ecosystem feedbacks enhance nitrogen-fixing cyanobacteria blooms and complicate management in the Baltic Sea. AMBIO 36: 186-194.

Voss, M., J.W. Dippner, C. Humborg, J. Hürdler, F. Korth, T. Neumann, G. Schernewski, and M. Venohr. 2011. History and scenarios of future development of Baltic Sea eutrophication. Estuarine, Coastal and Shelf Science 92: 307-322.

Voss, M., K.-C. Emeis, S. Hille, T. Neumann, and J.W. Dippner. 2005. Nitrogen cycle of the Baltic Sea from an isotopic perspective. Global Biogeochemical Cycles 19: GB3001. doi: 10.1029/2004GB002338.

\section{AUTHOR BIOGRAPHIES}

Kari Eilola $(\bowtie)$ is an oceanographer at the SMHI. His research interests include physical and biogeochemical modeling of the Baltic Sea.

Address: Swedish Meteorological and Hydrological Institute, Sven Källfelts gata 15, 42671 V Frölunda, Sweden.

e-mail: kari.eilola@smhi.se

Elin Almroth Rosell has a Ph.D. in chemistry from Göteborg University and is working as a researcher in oceanography at the SMHI. The research interest is marine chemistry, field studies of biogeochemistry processes and ecological modeling.

Address: Swedish Meteorological and Hydrological Institute, Sven Källfelts gata 15, 42671 V Frölunda, Sweden.

e-mail: elin.almroth@smhi.se
Christian Dieterich is an oceanographer at the SMHI. His research interests include natural climate variability, its impact on ecosystems, ocean dynamics and numerical modeling.

Address: Swedish Meteorological and Hydrological Institute, 60176 Norrköping, Sweden.

e-mail: christian.dieterich@smhi.se

Filippa Fransner is a master student in Environmental Fluid Mechanics at Joseph Fourier University, Grenoble. Her research interests include physical oceanography and biogeochemistry of the oceans.

Address: Swedish Meteorological and Hydrological Institute, 60176 Norrköping, Sweden.

e-mail: filippa.fransner@hotmail.com

Anders Höglund has a Ph.D. in mathematics from Linköpings Universitet and is currently working as a researcher in oceanography at the SMHI. Current research interest includes current patterns in the Baltic Sea.

Address: Swedish Meteorological and Hydrological Institute, 60176 Norrköping, Sweden.

e-mail: anders.hoglund@smhi.se

H. E. Markus Meier is adjunct professor at Stockholm University and head of the Oceanographic Research Unit at the Swedish Meteorological and Hydrological Institute (SMHI). His current research interests focus on the analysis of climate variability and the impact of climate change on the physics and biogeochemical cycles in the Baltic Sea, North Sea and Arctic Ocean.

Address: Swedish Meteorological and Hydrological Institute, 60176 Norrköping, Sweden.

e-mail: markus.meier@smhi.se 